courses in General Science, the class should by all means be small, and the demonstration sufficiently informal, so that the pupils can come near the lecture table to see what is going on, and to get a bit, at least, of the "feel" of the apparatus.

As has already been said, the methods of instruction may vary, but the purpose of the General Science course must be substantially the same, whether the course is given in the Junior High School or in the four-year High School. The understanding of the world about him is what the pupil needs. In his life experience the pupil will get more of the "practical" and "commercial" than he will of the cultural, which is, after all has been said, the fundamental. Therefore, the science courses should give him some basic knowledge of those phenomena and laws which, for special purposes, we call physical, chemical, and biological. These are the only sure foundations for a sane study of the future, whether of practical subjects or of further eultural studies. This is true likewise for the growing knowledge which will come even to those whose means or condition render further schooling of the formal sort impossible. Science study is a sane preparation for a sane State.

\title{
THE SCIENTIFIC CURRICULA IN HIGH SCHOOLS AND THE TEACHING OF DISEASE PREVENTION. ${ }^{1}$
}

By Clarence W. East, M. D.

Department of Health, Springfield, Ill.

The scientific curricula in high schools vary within fairly definite limits. Sangamon County, Illinois is taken as a representative county, presenting urban, small town and country conditions. It has one city of 60,000 inhabitants and numerous towns of from less than 100 to 2,000 population. It presents an industrial, an agricultural and a mining community, each on a large scale.

Its high schools are those of a capitol city and a number of township high schools. We may assume that its high school curricula are representative.

The sciences taught are physics, chemistry, general sciences, meaning botany and zoology, and household sciences. By the latter is comprehended the selection and cooking of food stuffs and the selection and construction of simple garments for women and children. For the sake of being comprehensive we may add to this list physical culture and athleties.

\footnotetext{
1Regd before the Biology Sections of the C. A. S. \& M. T. Soldan High Sehool, St. Louis, Nov, 25, 1921.
} 
The subject further analyzed may be presented as follows:

I. What is taught of disease prevention directly.

II. What is taught by implication.

III. What additions should be made to the curricula.

I. What is taught of disease prevention directly.

Examination of text books reveals nothing at all. Questioning of teachers reveals that an occasional teacher may point out a few implications of morbid bacteriology in the biology course. Observation and acquaintance with a large number of high school pupils reveals nothing at all. The writer has three children, two of whom have graduated from high school and one of whom is now a first year student.

One of them taught four and one-half years in high school and one of them now teaches the sciences in a high school.

These all are like the Hebrew children in the fiery furnace, not a smell of fire (as far as disease prevention is concerned) having passed upon their garments.

Is this negative view borne out in household science and in physical eulture?

Household sciences are taught uniformly from the viewpoint of economics. Household sciences mean household economics as far as high school curricula are concerned.

Physical culture yields nothing directly. It is uniformly taught from the viewpoint of aesthetics to the many, and from the viewpoint of athletics to the few.

To this negative view must be added the fact that a large number of pupils do not take the scientific courses, and -a few in most schools must be excused from even the courses in physical culture.

II. What is taught of disease prevention by implification in the scientific curricula of high schools?

This depends upon two factors, the individual bent of science teachers and physical directors, and the deducing habits of high school pupils.

In physics, the vocational outlook is almost exclusively taught. Engineering and electricity are generally before the pupils' minds who take this course, with the exception of the few who are preparing for medicine and pedagogy. Sanitary science. is rarely suggested by the high school physics course, and rarely deduced by the pupil. Chemistry is in the same class with physics: A few will teach, a few will study medicine and sanitary seience. The majority who take chemistry seriously are thinking of commercial chemistry. 
Physical culture yields some results in disease prevention incidentally. It intermits the physical attitudes and mental concentration of study. It may assist muscular development, though it takes for granted nutritional balance and absence of physical defects. Its contribution to disease prevention is meagre.

Athletics is in the hands of the coach who must produce winning teams. Athletics not infrequently produces the cardiac and the neurasthenic patient.

An occasional pupil may infer the fact that morbid bacteriology is a part of botany, but this inference is by no means common. Even in agricultural courses, the parallelism between parasitism in plants on the one hand and animals, including humans on the other, is rarely inferred.

As addendum civies may be dragged in, which is invariably taught as political economy not including the health of the body politic. Even a visit to the city water works by the civics class lays no emphasis upon the potable qualities which the plant is supposed to secure, but rather upon its cost per unit to the householder and its production of revenue to the city.

III. What additions should be made to the curricula?

This writer declines to say. $\mathrm{He}$ is not a pedagogue. He has no special knowledge of curricula and their formation. $\mathrm{He}$ is here by invitation and freely acknowledges all of his limitations.

The facts herein presented may speak for themselves. The following suggestions are added.

1. Public Health now approaches the whole school system as an intruder, often welcome, sometimes unwelcome, through the school physician in the majority of the cities of the firstclass, and in the minority of lesser cities.

2. The public school nurse touches a great many schools, but only occasionally the high schools. She functions by sufferance except in case of actual epidemic.

3. The disagreeable phases of public health, such as quarantine and vaccination against small pox are all that usually reaches any portion of the public school population. They share this not exclusively but with all other members of the community.

4. Communicable Disease produce over 50 per cent of human morbidity. They are preventable in proportion to general intelligence and honest administration of sanitary laws.

5. Hygiene and public health are not sectarian subjects, neither are they preserves of specialists. They are fundamental 
to race betterment, to citizenship, to efficiency and to a broad culture.

6. The inclusion of courses in hygiene and public health in teacher training is suggested as the method of greatest immediate value in the teaching of disease prevention in high schools.

The present science teachers in high schools are high school pupils one or more years removed as far as training in sciences is concerned. If there has been any broadening in their seience training in a generation it is toward vocational and economic ends, and little if any toward public health.

\section{THE USE OF MOTION PICTURES IN PHYSICS TEACHING. ${ }^{1}$}

By Harvey B. Lemon.

\section{University of Chicago, Chicago, Ill.}

Of the various methods at present most effective in physics teaching, the most important are probably in the following order:

Laboratory work

Classroom recitation and problem solving

Demonstration lectures.

In the University of Chicago, for many years the demonstraton lecture was not utilized to any large extent. The reasons for this were several. In the first place, demonstration lectures require, if they are to be effective, a large amount of time in preparation. Experiments, which occupy perhaps an hour to show, may require three or four hours to set up beforehand. In the second place, it is not always possible to correlate demonstration material with classroom work and laboratory exercises that are going on at the same time; and much of value in them is therefore lost by not immediately being applied. On the other hand, it is generally felt that in subjects like physics and chemistry, there are many extremely important illustrations of modern applications and of ratber striking character which can be brought into the course only through the medium of the demonstration lecture. Also, men of great distinction in special fields of work can be brought before elementary classes on one or two occasions during the year with lectures of this type. With these men, elementary students naturally have no contact in routine laboratory or elassroom work. For these two reasons then, the demonstration lecture has been revived in physics teaching at Chicago with no small amount of success, and one

1Read before the General Section of the C. A. S. and M. T. at the Soldan Figh School St. Irouis, Nov. 25, 1921 . 